\title{
Dendritic Cells are preferentially targeted among hematolymphocytes by Modified Vaccinia Virus Ankara and play a key role in the induction of virus-specific $T$ cell responses in vivo Luzheng Liu*1,2, Rahul Chavan²,3 and Mark B Feinberg ${ }^{2,4}$
}

Address: ${ }^{1}$ Harvard Skin Disease Research Center, Department of Dermatology, Harvard Medical School, Brigham and Women's Hospital, Boston, MA 02115, USA, ${ }^{2}$ Emory Vaccine Center, Emory University School of Medicine, Atlanta, GA 30329, USA, ${ }^{3}$ University of South Florida College of Medicine, Tampa, FL 33612, USA and ${ }^{4}$ Merck Vaccine Division, West Point, PA 19486, USA

Email: Luzheng Liu* - lzliu@ rics.bwh.harvard.edu; Rahul Chavan - rahulnchavan@yahoo.com; Mark B Feinberg - mark_feinberg@merck.com

* Corresponding author

Published: 15 April 2008

BMC Immunology 2008, 9:15 doi:10.1186/147/-2172-9-15
Received: 9 December 2007

Accepted: 15 April 2008

This article is available from: http://www.biomedcentral.com/I47/-2/72/9//5

(C) 2008 Liu et al; licensee BioMed Central Ltd.

This is an Open Access article distributed under the terms of the Creative Commons Attribution License (http://creativecommons.org/licenses/by/2.0), which permits unrestricted use, distribution, and reproduction in any medium, provided the original work is properly cited.

\begin{abstract}
Background: Modified Vaccinia Ankara (MVA) is a highly attenuated strain of vaccinia virus (VV) that has lost approximately $15 \%$ of the VV genome, along with the ability to replicate in most mammalian cells. It has demonstrated impressive safety and immunogenicity profile in both preclinical and clinical studies, and is being actively explored as a promising vaccine vector for a number of infectious diseases and malignancies. However, little is known about how MVA interacts with the host immune system constituents, especially dendritic cells (DCs), to induce strong immune responses despite its inability to replicate in vivo. Using in vitro and in vivo murine models, we systematically investigated the susceptibility of murine DCs to MVA infection, and the immunological consequences of the infection.
\end{abstract}

Results: Our data demonstrate that MVA preferentially infects professional antigen presenting cells, especially DCs, among all the subsets of hematolymphoid cells. In contrast to the reported blockage of DC maturation and function upon VV infection, DCs infected by MVA undergo phenotypic maturation and produce innate cytokine IFN- $\alpha$ within $18 \mathrm{~h}$ of infection. Substantial apoptosis of MVA-infected DCs occurs after $12 \mathrm{~h}$ following infection and the apoptotic DCs are readily phagocytosed by uninfected DCs. Using MHC class I - deficient mice, we showed that both direct and cross-presentation of viral Ags are likely to be involved in generating viral-specific $C D 8^{+}$ $\mathrm{T}$ cell responses. Finally, DC depletion abrogated the T cell activation in vivo.

Conclusion: We present the first in vivo evidence that among hematolymphoid cells, DCs are the most susceptible targets for MVA infection, and DC-mediated Ag presentation is required for the induction of MVA-specific immune responses. These results provide important information concerning the mechanisms by which strong immune responses are elicited to MVA-encoded antigens and may inform efforts to further improve the immunogenicity of this already promising vaccine vector. 


\section{Background}

The success of the prototype poxvirus vaccinia virus (VV) to eradicate naturally occurring smallpox worldwide stands as one of the most remarkable medical achievements in human history [1]. This achievement came at a price, however. Inoculation with live VV can overwhelm the immune system of immunocompromised individuals, causing significant morbidity and mortality $[2,3]$. As a result of this realization, toward the end of the smallpox immunization campaign, a highly attenuated VV strain, modified vaccinia virus Ankara (MVA), was developed for use in individuals at high risk of $\mathrm{VV}$-associated adverse events. MVA has since been safely administrated to over 120,000 individuals in the late stages of the smallpox eradication effort [4]. MVA lost approximately $15 \%$ of the vaccinia genome in the course of over 500 passages in chicken embryonic fibroblasts ex vivo, along with the ability to replicate in most primary mammalian cells $[4,5]$. Compared to replicating VV, MVA provides similar or higher levels of endogenous or recombinant gene expression even in non-permissive cell lines, higher but more transient Ag expression in vivo, and comparable levels of immune responses in animal models [6-12]. In light of this favorable degree of immunogenicity, combined with its highly attenuated phenotype and associated inherent safety properties, MVA is being actively explored as a promising vaccine vector in both preventative and therapeutic indications for a number of infectious diseases and malignancies. In addition, MVA has also been the subject of renewed interest and clinical evaluation as a safer vaccine to prevent smallpox in light of concerns about potential bioterrorist threats and the increased sensitivity to vaccine safety considerations especially at a time when far more individuals with acquired immunodeficiency (by virtue of either therapeutic immunosuppression or HIV infection) are present in the population than when the smallpox eradication campaign was mounted $[11,13,14]$.

Murine models represent an extensively utilized preclinical experimental system for vaccine development. In the case of MVA, the murine model has been employed, to date, to study both MVA-induced cellular and humoral immune responses, as well as the efficacy of protection following experimental pathogenic VV challenge $[15,16]$. However, little has been done to understand how this highly attenuated non-replicating virus activates both branches of the immune system. Of particular interest, few systematic studies have been carried out to investigate the interaction between MVA and murine dendritic cells (DCs), the most potent APCs to activate naïve CD4 and CD8 T cells [17]. In contrast, there has been considerable interest and effort invested in the study of the interaction of VV and human DCs, and to a somewhat lesser extent, the interaction between MVA and human DCs $[12,18]$. VV has been shown to abortively infect human DCs, block their maturation, inhibit their phagocytosis and directional migration, and to induce extensive DCs apoptosis [19-22]. These observations suggest that targeted infection of human DCs by VV may be an important viral strategy to circumvent host immune defenses. All of these studies employed human monocyte-derived DC (MoDC) cultures. It has not been assessed, in the very tractable murine model system, how and to what extent specific consequences of poxvirus infection of DC manifested in culture predict the ability of the host to generate antiviral immune responses in vivo. Since MVA has lost multiple host range genes as well as immunomodulatory genes present in the parental VV genome [5,23], it is conceivable that the target cell tropism of MVA may differ from that of $\mathrm{VV}$, and MVA might activate instead of suppress the maturation and function of DC, as suggested for VV.

In the current study, we sought to investigate the following questions in murine models: (1) the susceptibility of DCs to MVA infection; (2) the phenotypic and functional alteration of DCs upon MVA infection; (3) whether DCs activate T cells via direct or cross-presentation, and (4) whether DCs are required for in vivo T cell priming following MVA infection. Knowledge gained from these studies can provide important information concerning the mechanisms by which strong immune responses are elicited to MVA-encoded antigens.

\section{Results \\ Murine professional APCs are preferentially targeted by MVA among hematolymphoid cells, with DCs being the most susceptible targets}

To study whether murine DCs are susceptible to MVA infection, naïve $\mathrm{BALB} / \mathrm{c}$ splenocytes were infected in vitro with rMVA-GFP at a MOI of 10 for $8 \mathrm{~h}$ followed by flow cytometric detection of EGFP expression in different cell populations. As shown in Fig. 1A, despite the presumed broad cellular tropism of VV and related viruses, rMVAGFP did not infect all subsets of splenocytes to an equivalent extent, but rather demonstrated a striking preference for professional APC populations, with $\mathrm{CD} 11 \mathrm{c}^{+} \mathrm{DCs}$ being the most susceptible targets for MVA infection in the spleen $\left(31.2 \pm 2.9 \% \mathrm{GFP}^{+}\right)$, followed by $\mathrm{CD} 11 \mathrm{~b}^{+}$ CD11c- macrophages $\left(20.1 \pm 2.8 \% \mathrm{GFP}^{+}\right)$and $\mathrm{CD} 19^{+} \mathrm{B}$ cells $\left(8.5 \pm 2.1 \% \mathrm{GFP}^{+}\right)$. Very few $\mathrm{GFP}^{+}$cells were detected in $\mathrm{CD}^{+}(6.9 \pm 1.2 \%)$ and $\mathrm{CD}^{+}(3.6 \pm 1.5 \%) \mathrm{T}$ cell populations. Further phenotypic analysis revealed that over $50 \%$ of all $\mathrm{GFP}^{+}$cells were CD $11 \mathrm{c}^{+}$DCs (data not shown). Therefore, professional APCs, especially DCs and macrophages, seem to be preferentially targeted by MVA among all the splenocytes subsets in the in vitro infection setting. This was held true when splenocytes were infected at a range of MOIs (from 0.3 to 10) (data not shown). At all the MOIs tested, DCs were by far the most susceptible tar- 

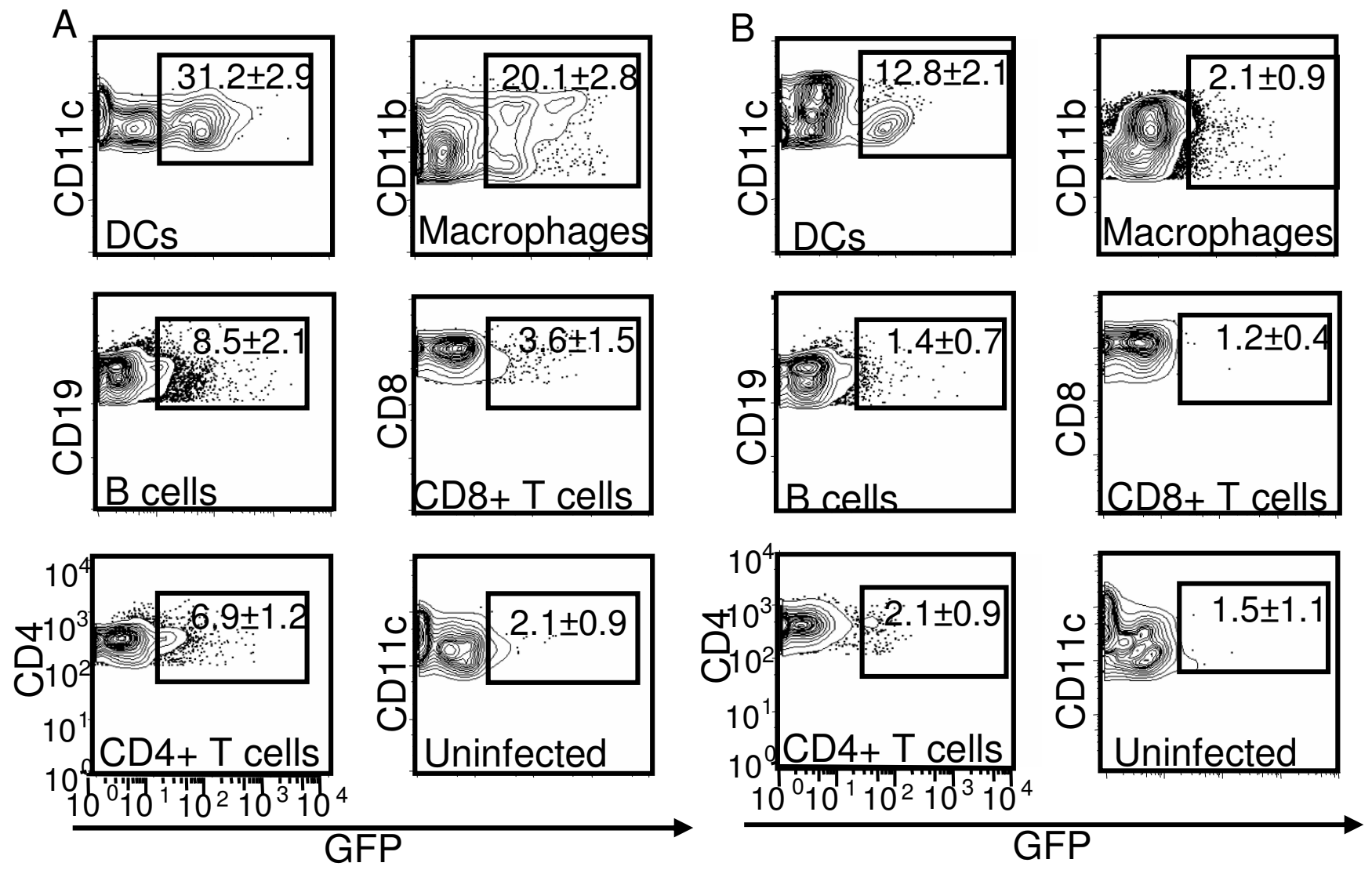

Figure I

MVA preferentially targeted professional APCs, especially DCs, both in vitro and in vivo. (A) Splenocytes from naïve BALB/c mice were infected with rMVA-GFP at a MOI of 10 in vitro for $8 \mathrm{~h}$ followed by cell surface marker staining and flow cytometry analysis. Uninfected splenocytes were used as negative control. (B) BALB/c mice were either uninfected or infected with rMVA-GFP at $3 \times 10^{8} \mathrm{PFU} /$ mouse by i.v. injection. Spleens were harvested at $9 \mathrm{~h}$ post infection and GFP expression in various subsets of splenocytes was monitored by flow cytometry. DCs: CDI l c ${ }^{+}$; macrophages: $C D I b^{+} C D I I c^{-} ; B$ cells: $\mathrm{CD} 9^{+}$; $\mathrm{CD}^{+} \mathrm{T}$ cells: $\mathrm{CD}^{+} \mathrm{CD}$ I lc; $\mathrm{CD}^{+} \mathrm{T}$ cells: CD4 ${ }^{+} \mathrm{CDI}$ lc-. Numbers shown are the percentages (average \pm standard deviation (SD)) of $\mathrm{GFP}^{+}$cells in the corresponding cell subsets. The data are representative of three independent experiments.

gets among all the splenocytes subsets, followed by macrophages and B cells.

To confirm the cellular tropism of MVA infection in vivo, we infected BALB/c mice intravenously with $3 \times 10^{8} \mathrm{PFU}$ rMVA-GFP. At various time points post infection, spleens were harvested and MVA infected GFP+ splenocytes were identified by cell lineage marker staining and flow cytometry. The number of $\mathrm{GFP}^{+}$cells in spleen peaked at $9 \mathrm{~h}$ post infection and rapidly declined to undetectable level by 24 $\mathrm{h}$ post infection (data not shown). At $9 \mathrm{~h}$ post infection, GFP expression was primarily detected in $\mathrm{CD} 11 \mathrm{c}^{+} \mathrm{DC}$ population $\left(12.8 \pm 2.1 \% \mathrm{GFP}^{+}\right)$, but not any other cell types including macrophages, as shown in Fig. 1B. This result suggests that MVA preferentially infects DCs in secondary lymphoid organ in vivo. Since DCs are vastly out- numbered by B cells, T cells in spleen, this result, together with the in vitro infection data (Fig. 1A), establish that among various subsets of hematolymphoid cells, DCs are preferentially targeted by MVA in a highly effective manner.

\section{MVA abortively infect murine DCs, with viral life cycle arrested before late gene expression}

MVA has lost its ability to replicate in most primary mammalian cells. The defect in the viral life cycle has been shown to be the final steps of viral morphogenesis, with no alteration in early or late virus gene expression [6]. To determine whether both early and late MVA genes were expressed from the infected murine DCs, we measured the expression of GFP (driven by an early promoter) and a late viral gene A56R from the in vitro MVA-infected 
BMDCs as well as purified CD $11 \mathrm{c}^{+}$splenic DCs, as described in Methods. The permissive chicken embryonic fibroblasts DF-1 cells were infected in parallel as positive controls for MVA gene expression. Cells were infected with rMVA-GFP at a MOI of 10 for $20 \mathrm{~h}$. The cells were then harvested and subjected to intracellular staining for anti-A56R mAb, as described in Methods. As shown in Fig. 2 , the expression of the early gene GFP was easily detected in over $60 \%$ of cultured BMDCs and $40 \%$ of splenic DCs. However, no A56R (late gene) expression was detected in either DC preparations (Fig. 2A\&B), while almost 100\% DF-1 cells expressed both GFP and A56R. Therefore, the MVA life cycle is blocked in murine DC at an earlier stage than the virion assembly defect reported for other nonpermissive mammalian cell lines $[6,12]$. These data are consistent with the report that only early but not late MVA genes are expressed from the infected human DCs [12,24].

\section{Upon MVA infection, BMDC underwent rapid maturation} and produced significant amount of IFN- $\alpha$

Targeted infection of MoDC by VV has been suggested as a viral immune evasion strategy, as DC maturation was shown to be blocked by WV infection $[20,24]$. To study whether MVA infection affects the maturation process of murine DC, we monitored the expression of maturation markers by DCs following rMVA-GFP infection. Initially splenic DCs were used in the experiments. However, these cells underwent rapid apoptosis within $12 \mathrm{~h}$ following in vitro isolation, even without infection (data not shown).
BMDCs were then used to study the effect of MVA infection of DC maturation. BMDCs were infected with rMVAGFP at a MOI of 10, mock-treated or stimulated with LPS. Mock-treated BMDCs were used to reflect the spontaneous BMDC maturation induced by the "mechanical" manipulation. LPS treatment was included to induce maximal BMDC maturation. At 0,12 and $18 \mathrm{~h}$ following infection, cells were harvested and stained with mAbs specific for CD40, CD86, CD80, and MHC class II I-A ${ }^{d}$. As shown in Fig. 3, as early as $12 \mathrm{~h}$ post infection there was a significant upregulation of all the maturation markers on the majority of infected BMDCs. By $18 \mathrm{~h}$ post infection, the virus-infected DCs further upregulated the maturation markers. The phenotype of the MVA-infected DCs was comparable to that of LPS-stimulated DCs at both $12 \mathrm{~h}$ and $18 \mathrm{~h}$ post infection. These data suggest that MVA infection induced rapid BMDC maturation. This is in direct contrast to the reported blockage of human DC maturation by VV infection $[19,20,24]$.

Activated DCs secrete an array of cytokines and chemokines that are crucial for amplification of both innate and adaptive immune responses [17]. To test whether MVA infection of murine DCs could induce cytokine production, we measured the secretion of the pro-inflammatory cytokine IFN- $\alpha$ from DCs following MVA infection. BMDCs and splenic CD $11 \mathrm{C}^{+}$DCs were either mocktreated or infected with rMVA-GFP at a MOI of 10. Supernatants were harvested at 10 and $24 \mathrm{~h}$ post infection, and

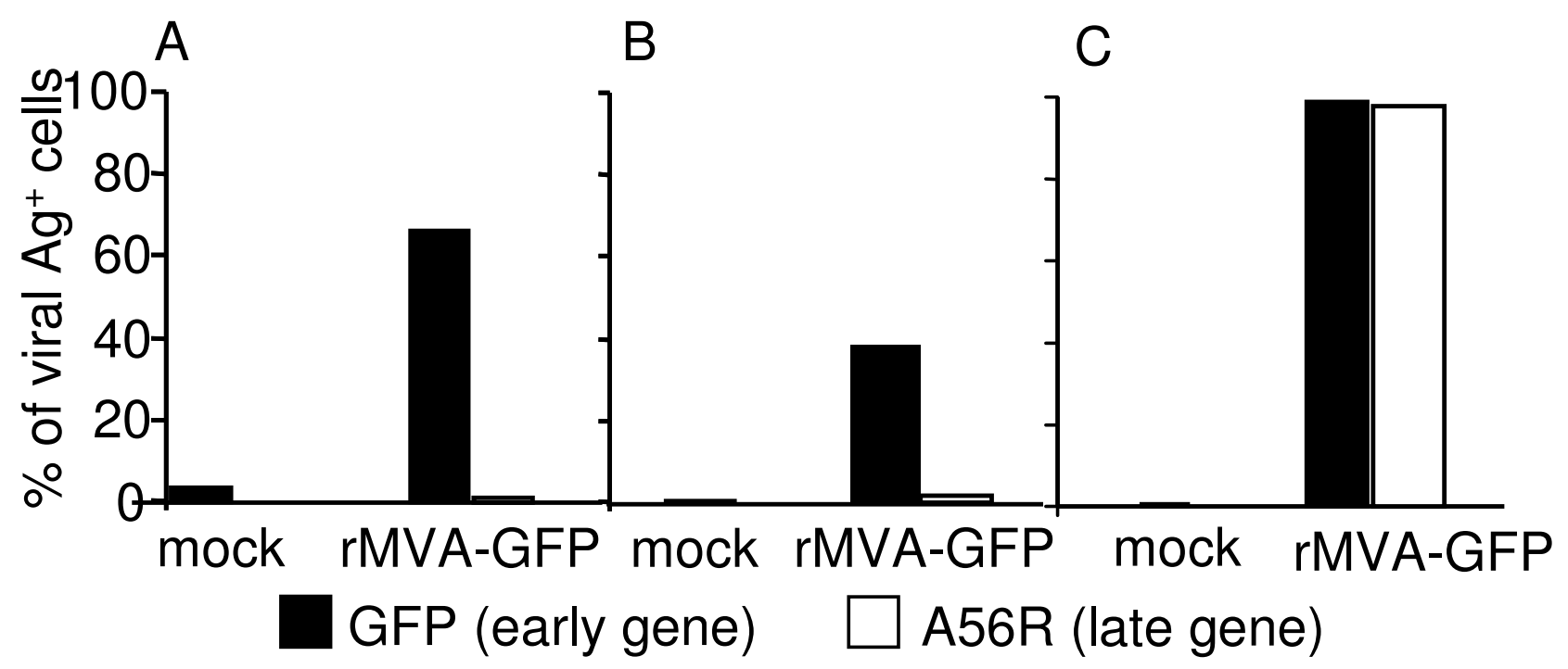

Figure 2

Only early but not late MVA genes were expressed from infected DCs. BMDCs $(A)$, splenic CDII ${ }^{+} D C s(B)$, and DF-I cells (C) were infected with rMVA-GFP at a MOI of I0. Mock-treated cells were included as negative controls. MVAencoded early gene (GFP) and late gene (A56R) expression was monitored $20 \mathrm{~h}$ post infection by flow cytometry. The data shown are representative of three independent experiments. 


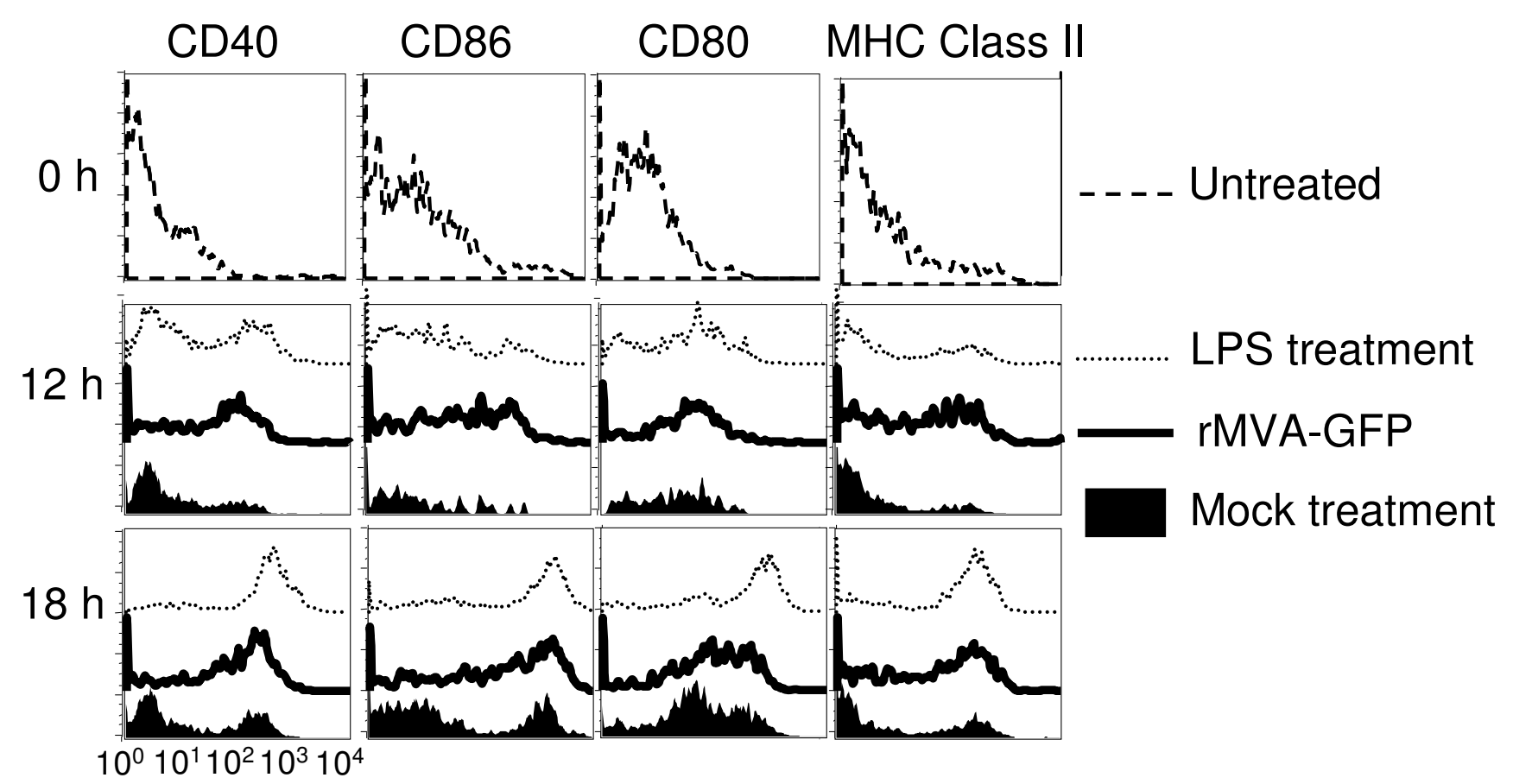

Figure 3

MVA infection induced rapid BMDC maturation. Immature BMDCs were mock treated, infected with rMVA-GFP at a $\mathrm{MOI}$ of 10 , or stimulated with $10 \mu \mathrm{g} / \mathrm{ml}$ LPS as described in Methods. At 0,12 and $18 \mathrm{~h}$ post treatment, cells were harvested and subjected to cell surface staining for the indicated maturation markers. Samples were analyzed by flow cytometry. Histograms were gated on GFP ${ }^{+}$cells. These data are representative of five independent experiments.

IFN- $\alpha$ levels were measured by ELISA. As shown in Fig. 4, substantial amount of IFN- $\alpha$ was readily detected from both BMDC and splenic DCs as early as $10 \mathrm{~h}$ after rMVA-
GFP infection. The amount of IFN- $\alpha$ detected in the supernatant samples was further increased by $24 \mathrm{~h}$ post infection. These results suggest MVA-infected DCs not only
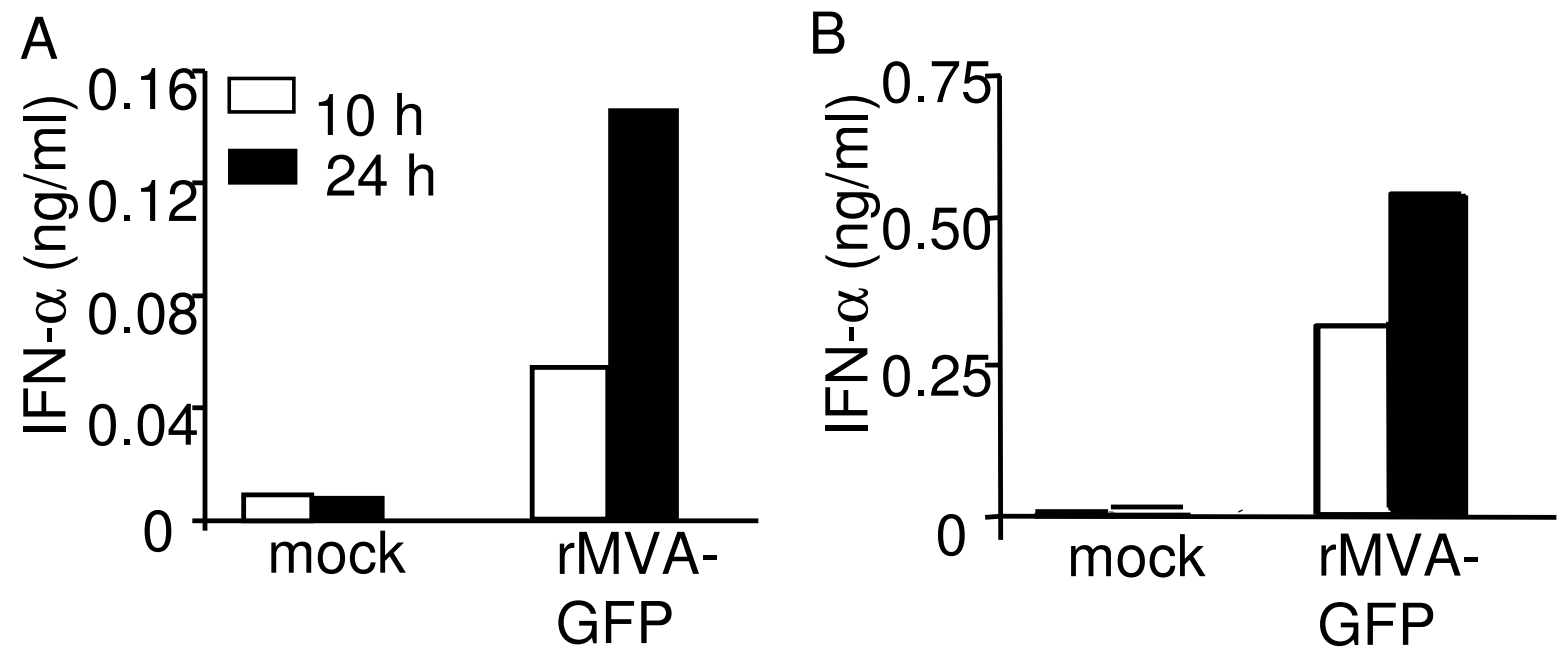

Figure 4

MVA infection induced IFN-aproduction from DCs. Immature BMDCs (A) or splenic CDII c $\mathrm{c}^{+} \mathrm{DCs}(\mathrm{B})$ were either mock treated or infected with rMVA-GFP at a MOI of 10. Supernatant samples were collected at $10 \mathrm{~h}$ and $24 \mathrm{~h}$ post infection for IFN- $\alpha$ detection by ELISA. These data are representative of three independent experiments. 
undergo rapid phenotypic maturation, but also are capable of prompting host immune responses via pro-inflammatory cytokine production. Noticeably, endogenous splenic DCs produced significantly higher amount of IFN$\alpha$ upon MVA infection compared to BMDCs (5-fold and 3 -fold difference at $10 \mathrm{~h}$ and $24 \mathrm{~h}$, respectively).

\section{DCs underwent substantial apoptosis following MVA} infection and were phagocytosed by uninfected DCs

Studies of VV infection of human MoDCs have suggested that DC undergo substantial apoptosis rapidly following the infection $[12,20]$. To study whether this is also true for MVA infected murine DC, we next assessed the viability of BMDCs at different time points following MVA infection. Immature BMDCs were either infected with rMVA-GFP at a MOI of 10 or mock treated. Cells were harvested at various time points following the treatment for viability count. As shown in Fig. 5A, immature BMDCs underwent substantial apoptosis starting $12 \mathrm{~h}$ following MVA infection, earlier than VV-infected BMDCs which did not undergo significant apoptosis until $18 \mathrm{~h}$ post infection (unpublished results). By $24 \mathrm{~h}$ following infection, only $50 \%$ of the MVA-infected cells remained viable, while $90 \%$ of mock-treated cells were still alive. Over $70 \%$ of the infected cell had been dead by $42 \mathrm{~h}$ following MVA infection. We further compared the viability of immature and mature BMDCs following rMVA-GFP infection. BMDCs were stimulated with LPS for $24 \mathrm{~h}$ to reach maturation. Both immature and mature BMDC were then infected with rMVA-GFP or mock-treated for $24 \mathrm{~h}$ and the cell viability was determined. As shown in Fig. 5B, MVA infection reduced the viability of both immature and mature BMDC compared to mock treatment. Interestingly, mature BMDCs displayed higher viability than immature BMDCs at this time point. This data suggests that upon maturation, DCs become somewhat more resistant to MVAinduced cell death. This may be of particular importance for direct antigen presentation.

The rapid apoptosis of MVA-infected DCs indicates substantial proportion of infected DCs may not present Ags to $\mathrm{T}$ cells directly, but rather be uptaken by uninfected bystander DCs for cross-presentation of the viral Ags. We then investigated whether the MVA- infected DCs undergoing apoptosis could be phagocytosed by uninfected DCs. Green fluorescence (PKH-67)-labeled BMDCs were first infected with rMVA for $18 \mathrm{~h}$, then incubated with red fluorescence (PKH-26)-labeled uninfected BMDCs at 1:1 ratio at either $37^{\circ} \mathrm{C}$ or $4^{\circ} \mathrm{C}$ for $4 \mathrm{~h}$. Phagocytosis were monitored by flow cytometry. Following incubation at $37^{\circ} \mathrm{C}$, one third of the uninfected DCs $(30.1 \pm 5.3 \%)$ became PKH-67+ $\mathrm{PKH}-26^{+}$, while few $(2.1 \pm 1.9 \%)$ uninfected DCs picked up PKH- $67^{+}$cells at $4{ }^{\circ} \mathrm{C}$ (Fig. 6). These data suggest that following MVA infection, the infected
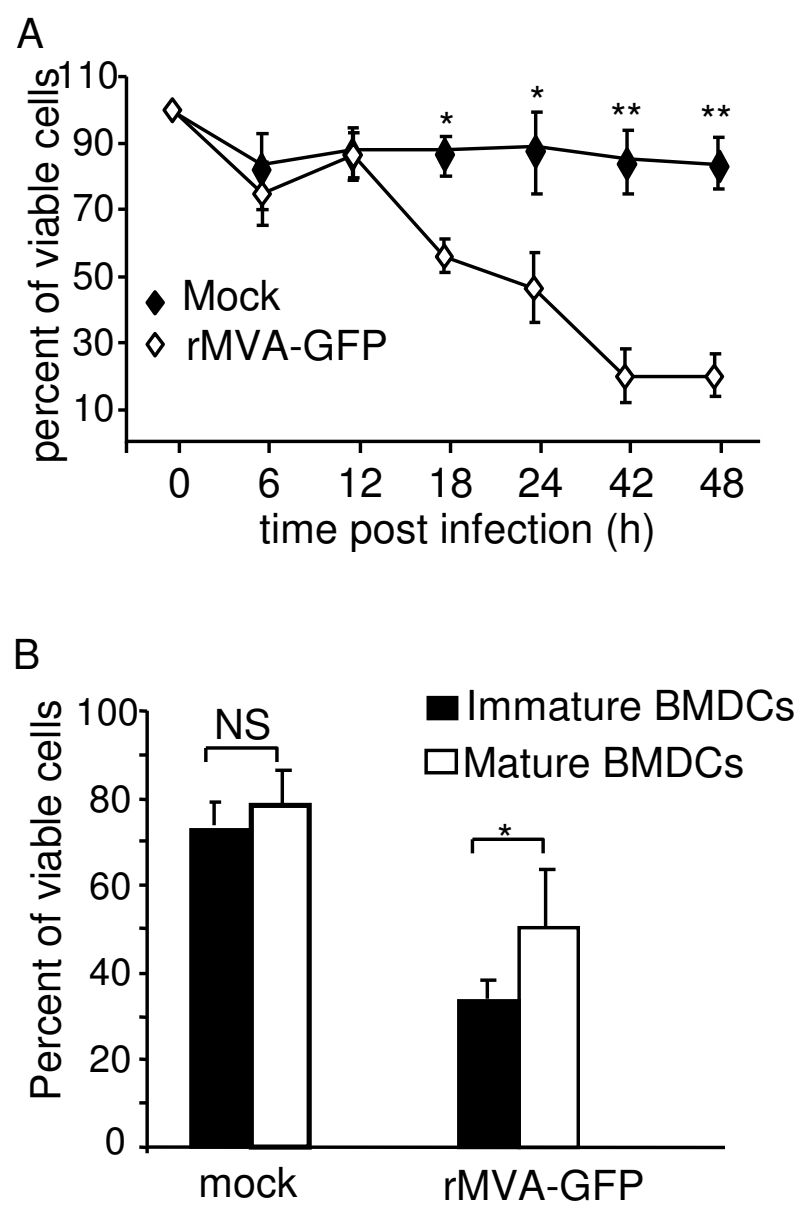

Figure 5

MVA infection significantly reduced the viability of BMDCs after $\mathbf{I} 2 \mathrm{~h}$ of infection. (A) Kinetic analysis of DC viability following MVA infection. Immature BMDCs were either mock treated, or infected with rMVA-GFP at a MOI of 10. At various time points, cells were harvested and viable cells were counted with trypan blue exclusion method. These data represent the average \pm SD viability of 6 replicates from 2 experiments. (B) Immature BMDCs and LPSstimulated mature BMDCs were mock treated or infected with rMVA-GFP at a MOI of I0. Twenty four hours later, cell viability was examined by trypan blue exclusion. These data represent the average $( \pm S D)$ viability of $I 5$ replicates from 5 experiments. NS: statistically non-significant; *: $\mathrm{P}<0.05$; **: $\mathrm{P}$ $<0.01$.

DCs can be engulfed by uninfected DCs efficiently and rapidly.

\section{MVA-infected DCs can induce viral antigen-specific CTL activity in vivo by both direct antigen presentation and cross-priming}

Having shown that MVA-infected DCs were readily phagocytosed by uninfected bystander DCs, we then 


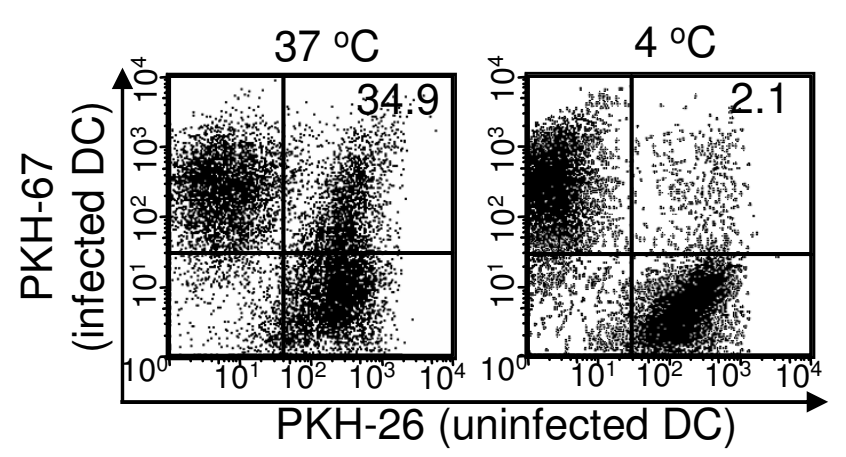

Figure 6

MVA-infected DCs were phagocytosed by uninfected DCs. Immature BMDCs were labeled with PKH-67 and infected with MVA at a MOI of 10 for $18 \mathrm{~h}$. They were then extensively washed and mixed with PKH-26-labeled uninfected immature BMDCs for $4 \mathrm{~h}$ at either $37 \mathrm{C}^{\circ}$ or $4 \mathrm{C}^{\circ}$. Phagocytosis of MVA-infected DCs by uninfected DCs were detected by flow cytometry. This data is representative of two independent experiments.

hypothesized that MVA Ags can be presented to T cells through cross-presentation. To test this hypothesis, rMVA expressing LCMV NP Ag (rMVA-NP) or rMVA-GFP was used to infect BMDCs from either WT C57BL/6 mice or MHC class I deficient $\beta 2 \mathrm{~m} /$ mice. DCs were infected at a MOI of 10 for $6 \mathrm{~h}$ before intravenously injected into LCMV immune mice. To prevent direct infection of host APCs by the infectious viruses co-injected with BMDCs, DCs were extensively washed and irradiated prior to the injection. Five days following DC injection, spleens were harvested and single cell suspensions were prepared and CTL activity specific to the dominant LCMV epitope $\mathrm{NP}_{396-404}$ was determined by fluorescent cellular cytotoxicity assay, as described in Methods. Strong $\mathrm{NP}_{396-404}$ specific CTL activity was detected in mice immunized by rMVA-NP-infected WT DCs, but not in mice immunized with rMVA-GFP-infected BMDCs (Fig. 7). Interestingly, $\mathrm{NP}_{396-404}$-specific CTL activity was also detectable, although to a lesser degree, in mice immunized with rMVA-NP-infected $\beta 2 \mathrm{~m}^{-} /$DCs. Since $\beta 2 \mathrm{~m}^{-} /$DCs cannot directly present MHC class I-restricted Ags to T cells, these data suggest that the detected CTL activity is due to crosspresentation of NP Ags by the endogenous APCs that have phagocytosed the injected $\beta 2 \mathrm{~m} /$ - DCs.

In vivo DC depletion abrogated the production of effector cytokine IFN- $\gamma$ by $T$ cells following MVA infection

To definitively answer the question whether DCs are responsible and required for the in vivo $\mathrm{T}$ cell activation following MVA infection, we took advantage of the CD11c-DTR mice that express human DT receptor under the control of the CD11c [25]. DT injection has been shown to effectively deplete CD11 $\mathrm{c}^{+}$DCs within $24 \mathrm{~h}$. We

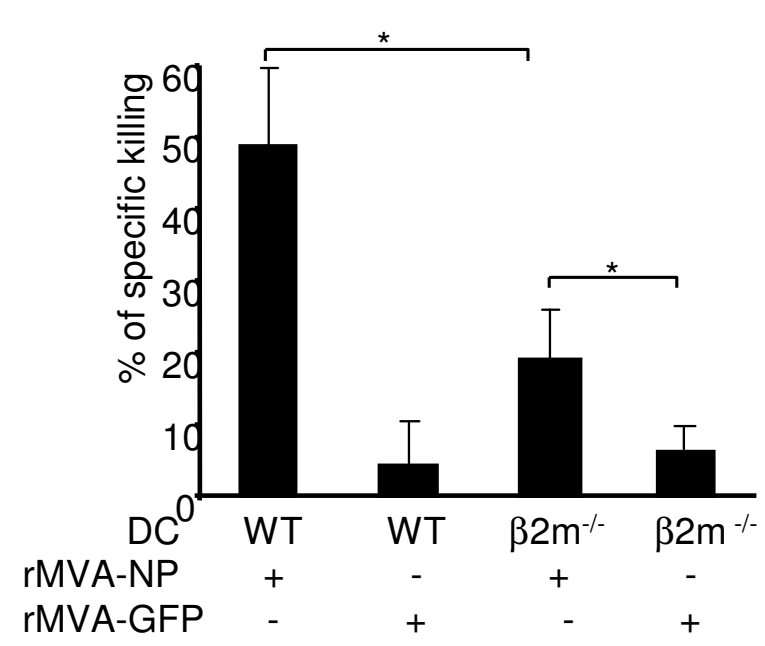

Figure 7

MVA-infected DCs induced Ag-specific CTL in vivo via both direct $\mathrm{Ag}$ presentation and cross-priming. BMDCs derived from either WT C57BL/6 (WT DCs) or $M H C$ class I-deficient $\beta 2 \mathrm{~m}^{-/-}$mice $\left(\beta 2 \mathrm{~m}^{-/-} \mathrm{DCs}\right)$ were infected with rMVA-NP or control rMVA-GFP at a MOI of 10 for $6 \mathrm{~h}$. The cells were washed and UV-irradiated to remove and inactivate any residual viruses. DCs were then intravenously injected into LCMV immune C57BL/6 mice I $\times\left(10^{6}\right)$. Five days later, $\mathrm{NP}_{396-404}$-specific CTL activity in spleens was assessed by fluorescent cellular cytotoxicity assay, as described in Methods. *: $\mathrm{P}<0.05$.

depleted DCs from CD11c-DTR mice by i.p. injection of DT (12 ng/g body weight) $[25,26]$ and infected the mice with $5 \times 10^{6}$ PFU MVA intraperitoneally $18 \mathrm{~h}$ later. DT injection was repeated on day 2 after infection to ensure continuous absence of DC. On day 6 after MVA infection, spleens were harvested and the efficiency of DC depletion was determined by flow cytometry. Over $95 \%$ of $C D 11 c^{+}$ DCs were depleted and the residual DCs had CD11clow $\mathrm{B} 220^{+}$phenotype, similar to that of plasmacytoid DCs (Fig. 8A). Single cell suspensions prepared from the spleens were re-stimulated with $\mathrm{C} 57 \mathrm{BL} / 6$ splenocytes infected with MVA for $6 \mathrm{~h}$ in the presence of Brefeldin A. Following the re-stimulation, the frequencies of IFN- $\gamma$ producing effector $\mathrm{CD} 3^{+} \mathrm{T}$ cells specific for MVA antigens were determined by intracellular IFN- $\gamma$-staining, as described in Methods. As shown in Fig. 8B, MVA-specific effector $\mathrm{T}$ cells producing IFN- $\gamma$ were detected in the spleens of WT littermates on day 6 after MVA infection. These cells accounted for $1.75 \pm 0.05 \%$ of total CD3 ${ }^{+} \mathrm{T}$ cells (Fig. 8C). However, in DC-depleted CD11c-DTR mice, we failed to detect any IFN- $\gamma$-production from $\mathrm{CD}^{+}$ T cells (Fig. 8B and 8C). These data suggest that DC-mediated $\mathrm{Ag}$ presentation is required for the generation of IFN- 

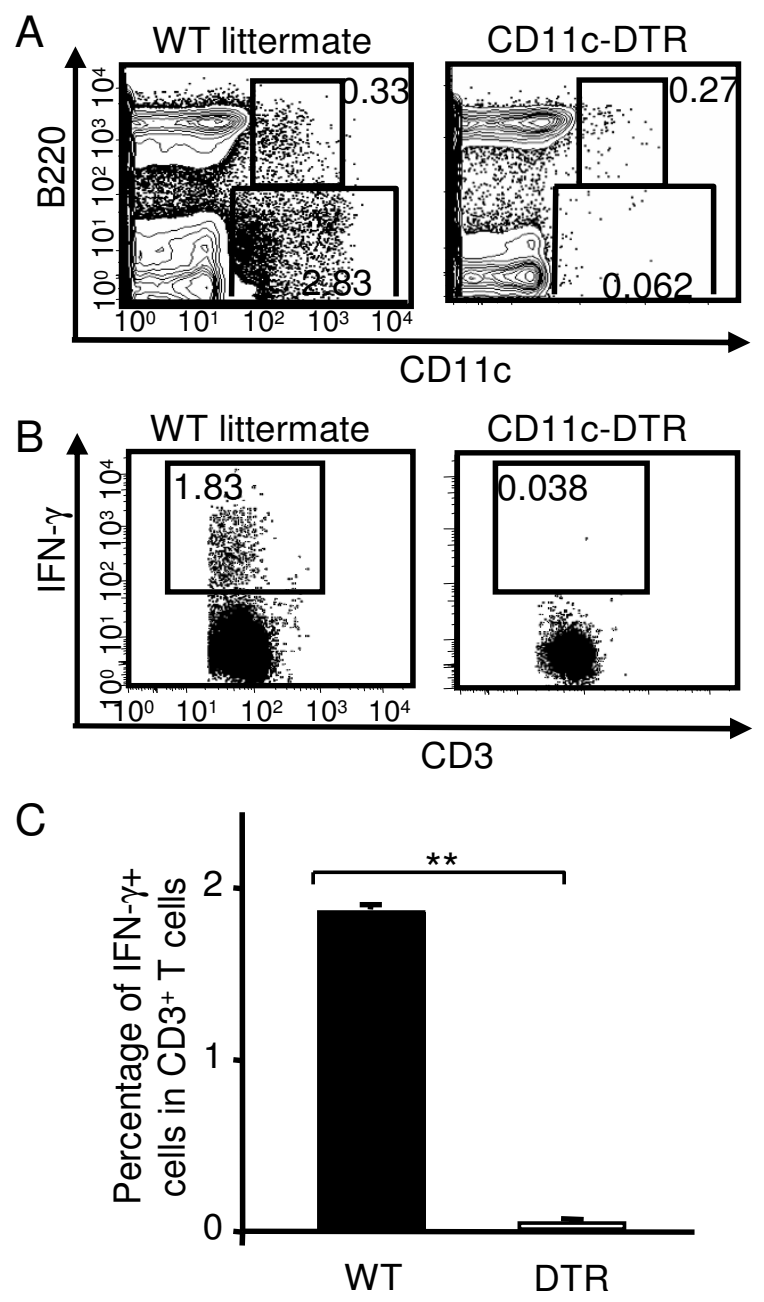

Figure 8

DCs were required for the generation of IFN- $\gamma$-producing effector $T$ cells following MVA infection. CDI I c-DTR mice were depleted of DC by i.p. injection of DT ( $12 \mathrm{ng} / \mathrm{g}$ body weight). Six hours after DT treatment, mice were i.p. infected with $5 \times 10^{6}$ PFU MVA. DT treatment was repeated on day 2 post infection. WT littermates were included as controls. At day 6 following the infection, spleens were harvested to prepare single cell suspension. (A) The efficiency of DC depletion was determined by surface cell lineage marker staining and flow cytometry. Numbers were the percentages of the gated population in total viable splenocytes. (B, C) Spleen single cell suspension (effector) was restimulated with MVA-infected C57BL/6 splenocytes (target) for $12 \mathrm{~h}$ in the presence of Brefeldin A. Following incubation, the frequencies of IFN- $\gamma$-producing $\mathrm{T}$ cells in the effector splenocytes were determined by intracellular cytokine staining, as described in Methods. Numbers were the percentages of IFN- $\gamma^{+}$cells in $\mathrm{CD}^{+} \mathrm{T}$ cell population. (C) The average \pm SD percentages of IFN $-\gamma^{+}$cells for each group $(n=4)$. Data are representative of two independent experiments. **: $\mathrm{P}<$ 0.01 . $\gamma$ producing effector T cells in vivo following MVA infection.

\section{Discussion}

rVVs are established tools for the development of vaccines against a wide range of infectious and malignant diseases $[15,16]$. Concerns about the safety of VV have led to the use of replication-defective viral vector systems, of which MVA is considered one of the safest and most promising candidates. Currently, at least three types of approaches have been used in MVA-based vaccine development [11]: (1) administration of MVA as primary vaccine or as a priming vector in the case of rMVAs expressing heterologous antigens; (2) administration of rMVA as booster vaccine following a primary immunization with an alternative vector encoding the same antigen of interest, such as delivered via DNA vaccination; and (3) immunization with DCs infected ex vivo with rMVA. Immunogenicity studies have shown that, compared to the replicating conventional VV vaccines, MVA vaccines can achieve similar or even higher levels of cellular and humoral responses and protect animals from lethal poxvirus challenge [6-12,27]. Although the mechanisms by which this highly attenuated non-replicating virus induces strong immune responses is not well-understood, it is conceivable that all these approaches ultimately depend on the capacity of DCs to induce Ag-specific T cell responses - given the central role of DCs in generating innate and adaptive immune responses. This is supported by the recent report that $\mathrm{CD} 11 \mathrm{c}^{+} \mathrm{DCs}$ isolated from Peyer's Patches and spleens of both MVA and VV-immunized mice induced substantial IFN- $\gamma$ production from an antigen-specific CTL line [27], although whether cell subsets other than DCs from the same lymphoid tissues could also be loaded with Ags and activate T cells was not tested in the study.

Current knowledge of the interaction of poxviruses with DCs is mostly derived from the studies of $\mathrm{VV}$ infection of human DC cultures. These studies have shown that VV abortively infects human MoDCs, inhibits their maturation, phagocytosis, and migration, and reduces the ability to stimulate allogeneic or autologous $\mathrm{T}$ cells in vitro [19$22,24,28]$. The suggestion that the perturbation of DC physiology observed in tissue culture infections of human DCs reflect a fundamental strategy of viral immune evasion is difficult to reconcile with the substantial humoral and cellular immune responses generated in VV-vaccinated individuals [29-31]. Whether the results from the in vitro studies accurately depict the in vivo VV-DC interaction is still an open question. Conflicting data have recently been reported regarding MVA infection of DCs. In one study, MVA was shown to induce immature human MoDC activation, based on the upregulation of co-stimulatory molecules and the secretion of pro-inflammatory 
cytokines [18]. Another study showed that MVA-infected immature human MoDCs failed to undergo maturation, but nevertheless were able to present viral Ags to the Agspecific human CTL line [12]. Using a murine model, Belyakov et al showed that endogenous DCs isolated from MVA immunized mice stimulated murine CTL lines in vitro [27]. However, the CTL lines used in these studies may have less stringent requirement than primary naïve $\mathrm{T}$ cells for co-stimulatory signals provided by APCs. Priming of naïve $\mathrm{CD}^{+} \mathrm{T}$ cells in mice immunized with MVAinfected immature BMDCs was demonstrated by Behboudi et al, even though the infected BMDCs downregulated MHC class I molecules and underwent apoptosis $[32,33]$. It was unclear in these studies whether MVA Ags were presented directly by MVA- infected DCs or indirectly via cross-presentation in these studies.

In the current report, we systematically characterized the interaction of MVA and host DCs using both in vitro and in vivo murine models to understand the role of DCs in MVA-induced immunogenicity. Using two different approaches, in vitro infection of splenocytes and in vivo infection of experimental mice, we first demonstrated that DCs are preferentially infected by MVA among various cellular components of the adaptive immune system (Fig. 1). This is consistent with our recent report of a similar DC tropism for VV infection in human PBMC [28]. Thus, despite the extensive loss of parental vaccinia host range genes from the MVA genome, the unique DC tropism of VV is well-conserved in MVA and thus may be of great biological importance for the interactions between poxviruses and the host immune system. The search for the cellular receptor(s) required for poxvirus binding and entry has continued for decades with little success. Our data suggest that the identification of poxvirus receptor(s) on DCs may greatly facilitate the design of DC-targeting $\mathrm{Ag}$ delivery system to further improve vaccine immunogenicity.

Infection of DCs by viruses could be either beneficial or harmful for the host immune system, depending on the subsequent phenotypic and functional changes of the infected DCs. For example, influenza virus and dengue virus infections lead to DC maturation and efficient T cell activation $[34,35]$. Consequently, the viruses are quickly cleared with resolution of the acute infection period. On the other hand, three viruses known to induce immunosuppression in humans, CMV, measles, and HIV, have all been documented to infect DCs directly and induce adverse functional alterations [36-39]. Our data support the contention that MVA infection efficiently induces murine DC maturation, manifested by the up-regulation of DC maturation markers (Fig. 3). We also demonstrated that following MVA infection, both BMDCs and splenic DCs secreted substantial amount of pro-inflammatory cytokine IFN- $\alpha$ (Fig. 4). These observations provide a rational explanation of MVA-induced immunogenicity, but are in direct contrast with the reported impairment of human DC maturation and function following VV infection [19-22,24,28]. The discrepancy could be attributed to or explained by a number of possibilities. First, it has been shown that, when viral gene expression was prevented by UV light or heat treatment, VV induced rapid human DC activation [18]. This suggests that the de novo synthesis of VV-encoded gene products interferes with DC maturation induced by viral binding or internalization per se. It is therefore possible that MVA infection of DCs may lead to distinct immunological consequences due to the deletion of the inhibitory genes from MVA genome. Second, MVA but not VV infection was shown to activate NF- $\kappa B$ in human embryonic kidney cells $[40,41]$. Since NF- $\mathrm{KB}$ activation is essential for DC activation and Ag presentation $[40,41]$, it is possible that MVA but not VV infection activates NF-kB-dependent pathways in DCs leading to their maturation. Third, in a concurrent study, we observed rapid maturation of murine BMDCs upon $\mathrm{VV}$ infection (unpublished data), suggesting possible species-specific and/or DC subtype-specific differences in the consequences of poxvirus infection on DCs.

Comparative studies of the MVA and $\mathrm{VV}$ genomes have revealed that many VV immune evasion genes that target host cytokine and chemokine functions have been lost from the MVA genome [5,42]. This has been proposed to at least partially compensate for the inability of MVA to replicate and sustain Ag production within hosts. Here, we show that a substantial amount of IFN- $\alpha$ was detected in the supernatant of MVA- infected DCs (both BMDCs and splenic DCs). Interestingly, when $\mathrm{VV}$ was used to infect BMDCs and splenic DCs, we failed to detect any IFN- $\alpha$ in the supernatant [see Additional figure 1A]. Furthermore, when known amount of recombinant IFN- $\alpha$ was added into the supernatant samples prior to ELISA, the recombinant IFN- $\alpha$ was no longer detected when added into VV-infected, but not MVA-infected, DC supernatant [see Additional figure 1B]. These data are consistent with the facts that vaccinia B18R gene encodes soluble high-affinity IFN- $\alpha / \beta$ receptors and the $\mathrm{B} 18 \mathrm{R}$ gene has been deleted from the MVA genome [43-45]. The importance of type I IFNs in the protective immunity against poxvirus infection is manifested by the attenuated virulence of B18R-knockout VV in both intranasally and intracranially infected mice $[43,44]$. Since type I IFN promote DC maturation and support $\mathrm{CD} 8^{+} \mathrm{T}$ cell and Th1 responses [46,47], IFN- $\alpha$ released from MVA-infected cells may contribute to the maturation of DCs following MVA infection and the subsequent induction of innate as well as cellular immune responses. 
We observed substantially reduced DC viability following MVA infection (Fig 5A). By $24 \mathrm{~h}$ after the infection, over $50 \%$ of DCs died. Similar to VV-induced cytopathy of human MoDC [20], we found that mature murine DCs are more resistant than immature murine DCs to MVAinduced death (Fig. 5B), and that MVA infection induced more DC apoptosis than VV infection (data not shown). The relatively higher susceptibility of DCs for MVAinduced cell death is consistent with our recent report that, compared with VV, MVA infection of human MoDCs leads to accelerated decline of intracellular anti-apoptosis

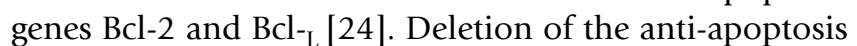
gene SPI-2 from the MVA genome may also contribute to decreased DC viability following infection $[24,48]$. Our in vivo experiments provide further evidence for rapid DC apoptosis upon rMVA infection. Following intravenous infection of mice with rMVA-GFP, the number of GFP+ cells in the spleen peaked at $9 \mathrm{~h}$ post infection and dropped sharply to background levels by $24 \mathrm{~h}$ post infection (data not shown). This result is in agreement with a report by Norbury et al which showed that the numbers of VV-infected cells in the draining lymph nodes following footpad injection decreased by $80 \%$ between 6 and $24 \mathrm{~h}$ post infection [49]. Although it is possible that the infected DCs were killed by a virus-specific immune response, as hypothesized by the authors, we think it is unlikely that naïve $\mathrm{T}$ cells could be called into action to kill in such a short period of time. Thus the disappearance of infected cells is more likely due to the direct cytopathic effect of the virus infection, as seen in our in vitro experiments.

It has been controversial whether $\mathrm{T}$ cell activation following poxvirus immunization is mainly due to direct $\mathrm{Ag}$ presentation by virus-infected DCs, rather than cross-presentation of viral Ags by uninfected DCs that have picked up the infected apoptotic cells [49]. Rapid maturation of MVA-infected DCs suggests that these DCs can directly activate $\mathrm{T}$ cells before they undergo apoptosis. On the other hand, substantial DC apoptosis in vitro and in vivo following MVA infection indicates that direct Ag presentation by the infected DCs is likely to diminish quickly and that cross-presentation of viral Ag by uninfected bystander DCs might be involved after the majority of the infected DCs have undergone apoptosis. In support of this hypothesis, we observed efficient phagocytosis of MVA-infected DCs by uninfected DCs (Fig. 6). Furthermore, when MVAinfected $\beta 2 \mathrm{~m}^{-/}$DCs were injected into mice, Ag-specific CTL activity was detected in the spleens, although at a lower level than in mice that received MVA-infected WT DCs. Similarly, Norbury et al. has shown that $\beta 2 \mathrm{~m}^{-/}$kidney cells infected with VV induced CD69 upregulation of $\mathrm{Ag}$-specific CD8 ${ }^{+} \mathrm{T}$ cells in vivo [50]. These results strongly suggest that both direct and cross-priming of CD8 T cells occur following poxvirus infection. $\mathrm{CD}^{+} \mathrm{T}$ cell cross- priming is further supported by the identification of late poxvirus gene-derived CTL epitopes in both human and mice [51], since the inability of DCs infected by either VV or MVA to express late viral genes prevents the direct presentation of late viral Ags.

We also observed MVA infection of macrophages and B cells, although to a lesser degree comparing to DCs. It remains unclear whether these cells can also present viral Ags and activate $\mathrm{T}$ cells in vivo following MVA infection. Using the CD11c-DTR mouse model that allows the conditional ablation of DCs in vivo, we unambiguously demonstrated that DC depletion abrogated the generation of Ag-specific effector T cells (IFN- $\gamma$-producing). Therefore, DCs (but not other APCs) play an essential role in the generation of MVA-specific T cells in vivo. The preferential infection of DCs by poxviruses could serve as an efficient Ag delivery system to the most crucial APCs for the induction of strong immune responses.

\section{Conclusion}

In summary, we present here the first systematic study of the interaction of MVA and murine DCs, using both in vitro and in vivo model systems. We demonstrate that professional APC, especially DCs, are preferentially targeted by MVA in secondary lymphoid tissues. The infected DCs express high levels of viral early Ags, undergo rapid maturation during the first $12 \mathrm{~h}$ post infection, produce substantial amount of IFN- $\alpha$, then become apoptotic in the next $24 \mathrm{~h}$. The infected DCs are readily taken up by uninfected bystander DCs, with their protein constituents then made available via cross-presentation mechanisms of antigen presentation to elicit virus-specific adaptive immune responses. DCs are required for the in vivo T cell activation, most likely via both direct- and cross-presentation of viral Ags. These results contribute to our understanding of the strong immunogenicity associated with the highly attenuated MVA and may be of great value for the design of safer and more effective vaccine vectors.

\section{Methods \\ Mice}

All animal work has been reviewed and approved by the Center for Animal Resources and Comparative Medicine at Emory University and Harvard Medical School. 6- to 8week-old female $\mathrm{BALB} / \mathrm{c}$ mice and $\mathrm{C} 57 \mathrm{BL} / 6$ mice were purchased from the Jackson Laboratories (Bar Harbor, ME). MHC class I-deficient B6.129P2-B2mtm1Unc $\left(\beta 2 \mathrm{~m}^{-} /\right.$ -) mice and CD11c-DTR-EGFP (CD11c-DTR) breeders [25] were purchased from the Jackson Laboratories and bred in a biosafety level-1 facility at Harvard Medical School. Virus-infected mice were housed in a biosafety level -2 facility. 


\section{Virus stocks}

rMVA strains were constructed to express GFP-ZEOCIN (rMVA-GFP) or lymphocytic choriomeningitis virus (LCMV) nuclear protein (NP) -ZEOCIN (rMVA-NP) $[28,52]$ under the control of the early H5 promoter and were plaque-purified at least 5 times as previously described using standard protocol [53]. Non-recombinant MVA stock used for the construction of rMVA was kindly provided by Dr. Bernard Moss (National Institutes of Health, Bethesda, MD). MVA for the phagocytosis experiment and for the infection of CD11c-DTR mice were kindly provided by Dr. Michael S. Seaman (Beth Israel Deaconess Medical Center, Boston, MA). rMVA-GFP and rMVA-NP stocks were prepared in and titered on the chicken embryo fibroblast cell line DF-1 (gift of Dr. Harold Varmus, National Institutes of Health, Bethesda, $\mathrm{MD})$. Viruses were concentrated by ultracentrifugation over 36\% (weight/volume) sucrose, and titers were determined using standard plaque assays. LCMV stocks (Armstrong strain) were kindly provided by Dr. Rafi Ahmed (Emory Vaccine Research Center, Atlanta, GA).

\section{Cells}

DF-1 and HeLa cells are described above. These cell lines were maintained in complete DMEM supplemented with 10\% FBS, 2 mM L-glutamine and antibiotics. EL4 cells (H$2^{\mathrm{b}}$ ) (ATCC) were maintained in RPMI supplemented with 10\% FBS, 2 mM L-glutamine and antibiotics. Splenic DCs were isolated from the spleens of $\mathrm{BALB} / \mathrm{c}$ mice that received daily injections of $20 \mu \mathrm{g}$ of recombinant flt3L$\mathrm{IgG}_{2}$ for 9 days $[54,55]$. Briefly, spleen fragments were digested with $1 \mu \mathrm{g} / \mathrm{ml}$ collagenase (Worthington, Lakewood, NJ) for $30 \mathrm{~min}$, followed by erythrocyte depletion with RBC lysing buffer (Sigma-Aldrich Co., St. Louis, $\mathrm{MO})$. DCs were then isolated from this single cell suspension using CD11c magnetic beads (Miltenyi Biotec, Auburn, CA) according to the manufacturer's instructions, and the purity of DCs was greater than $90 \%$ as evaluated by flow cytometry (data not shown).

Bone marrow-derived DCs (BMDCs) were generated from mouse bone marrow cultures as described previously with minor modifications [56]. Briefly, bone marrow was flushed from femurs and tibias and depleted of erythrocytes with RBC lysing buffer. Cells were subsequently plated on 6-well tissue culture plates at $4 \times 10^{6} /$ well in 3 ml complete RPMI 1640 medium (CM, contains 10\% FBS, $2 \mathrm{mM}$ L-glutamine, and $10 \mu \mathrm{g} / \mathrm{ml}$ gentamicin sulfate), incubated at $37^{\circ} \mathrm{C}$ for $3 \mathrm{~h}$, and then the non-adherent cells were removed. CM containing $10 \mathrm{ng} / \mathrm{ml} \mathrm{rmGM}-$ CSF and $3 \mathrm{ng} / \mathrm{ml}$ rmIL-4 (both from R\&D Systems, Minneapolis, $\mathrm{MN}$ ) was added at $3 \mathrm{ml}$ per well and the plates were incubated at $37^{\circ} \mathrm{C}$ for 1 week. Cultures were fed by gently aspirating $2 \mathrm{ml} /$ well of medium and adding back fresh CM containing cytokines on days 2, 4 and 6 of the culture. When mature DCs were required, $10 \mu \mathrm{g} / \mathrm{ml}$ LPS (Sigma-Aldrich Co.) was added to the culture on day 6 for $24 \mathrm{~h}$. On day 7, non-adherent cells were harvested, and the purity of the DCs culture was evaluated by cell surface staining with fluorescence-conjugated mAbs to CD11b (M1/70), CD11c (HL3), CD3 (145-2C11), and CD45R/ B220 (RA3-6B2) (BD Biosciences Pharmingen, San Diego, CA). Approximally $70-90 \%$ of the cells were CD $11 c^{+}$, as determined by flow cytometry (data not shown).

\section{Viral infection}

For in vitro infections, cells were resuspended at $1 \times 10^{7} /$ $\mathrm{ml} \mathrm{CM}$ in $15 \mathrm{ml}$ polypropylene tubes (Becton Dickinson Labware). An appropriate volume of the indicated virus stock was added to reach the multiplicity of infection (MOI) required for each experiment. Following $1 \mathrm{~h}$-incubation at $37^{\circ} \mathrm{C}$, cells were washed three times with medium, resuspended at $1 \times 10^{6} / \mathrm{ml}$ in CM on 24-well plates and cultured at $37^{\circ} \mathrm{C}$ until harvesting. Mock-treated cells were manipulated in the same way except that no virus was added. For in vivo i.v. infection, BALB/c mice were i.v. injected with $15 \mu \mathrm{g}$ DNA plasmid pNGVL3-hFLex [57] (obtained from National Gene Vector Laboratory, University of Michigan, and provided by Dr. Abdul M. Jabbar, Emory Vaccine Center) in $1.6 \mathrm{ml}$ PBS to expand DC population in vivo. Five days later, mice were infected i.v. with $3 \times 10^{8}$ plaque forming units (PFU) of rMVA-GFP in $0.5 \mathrm{ml}$ PBS. Uninfected mice were injected with $0.5 \mathrm{ml}$ PBS as controls. For intraperitoneal (i.p.) infection, CD11c-DTR mice and wild type (WT) littermates were infected with $2 \times 10^{6}$ PFU MVA.

\section{Cell surface staining and flow cytometry}

At the indicated time points post viral infection, splenocytes were stained with mAbs against CD3, B220, CD11b, CD11c, CD8a (Ly-2) (53-6.7), and CD4 (L3T4) (RM4-5) (BD Biosciences Pharmingen). At the indicated time points following in vitro infection, DF-1 cells, BMDCs, and splenic DCs were stained with purified anti-vaccinia late surface protein A56R using mAb VV1-4G9 (kindly provided by Dr. Alan Schmaljohn, USAMRIID, Frederick, $\mathrm{MD})$ and secondary PE-conjugated goat anti-mouse IgG (Biosource International, Camarillo, CA). BMDCs and splenic DCs were also stained with mAbs against DC maturation markers CD80 (16-10A1), CD86 (GL1), CD40 (5C3), and I-A d (AMS-32.1) (BD Biosciences Pharmingen). All staining steps were performed by incubating cells and $\mathrm{Abs}$ at $4^{\circ} \mathrm{C}$ for $20 \mathrm{~min}$ followed by three washes with staining buffer. Samples were then processed using a FACSCalibur flow cytometer (Becton Dickinson Labware) and the data were analyzed using Flowjo software (Tree Star, Inc., Ashland, OR). 


\section{Quantitation of IFN- $\alpha$ production by ELISA}

BMDCs or splenic DCs were mock- treated or infected with rMVA-GFP. Supernatant samples were harvested at 10 or $24 \mathrm{~h}$ following the treatment and stored at $-80^{\circ} \mathrm{C}$ if not used immediately. IFN- $\alpha$ in the supernatant was detected using a commercial colorimetric sandwich ELISA kit (R\&D Systems) according to manufacturer's instructions.

\section{Viability study}

Viability of BMDCs was determined by trypan blue exclusion at various time points following infection.

\section{Phagocytosis assay}

BMDCs were labeled with the green fluorescent dye PKH67 (Sigma-Aldrich Co.) according to the manufacturer's instructions and infected with MVA at a MOI of 10 for 18 h. They were then mixed with uninfected immature BMDCs labeled with the red fluorescent dye PKH-26 (Sigma-Aldrich Co.) for $4 \mathrm{~h}$ at either $37^{\circ} \mathrm{C}$ or $4^{\circ} \mathrm{C}$. Phagocytosis of infected DCs by uninfected DCs (PKH-67+ PKH$26^{+}$population) was visualized by flow cytometry.

\section{BMDC immunization and detection of cytotoxic $T$ lymphocyte (CTL) activity}

BMDCs derived from either WT C57BL/6 mice (B6.DCs) or $\beta 2 \mathrm{~m} /$-mice $(\beta 2 \mathrm{~m} /-\mathrm{DCs})$ were infected with rMVA-NP or control rMVA-GFP at a MOI of 10 for $6 \mathrm{~h}$. The cells were then extensively washed with PBS and UV-irradiated to inactivate any residual viruses and prevent co-injection of infectious MVA. They were then injected $\left(1 \times 10^{6}\right)$ into B6 mice that had been i.p.-infected with $2 \times 10^{5}$ PFU LCMV 30 days earlier. Five days after the DC injection, spleens were harvested and $\mathrm{NP}_{396-404}$-specific CTL activity was assessed by fluorescent cellular cytotoxicity assay as previously described [58]. Briefly, target EL4 cells were incubated at $37^{\circ} \mathrm{C} 5 \% \mathrm{CO}_{2}$ for $1 \mathrm{~h}$ in the presence of $1 \mu \mathrm{M}$ $\mathrm{NP}_{396-404}$ peptide and $3 \mu \mathrm{M}$ cell tracker orange (CTO, Invitrogen, Carlsbad, California). Cells were washed once with PBS and resuspended in CM at $1 \times 10^{6} / \mathrm{ml}$. Target cells and effector splenocytes from BMDC-immunized mice $(100 \mu \mathrm{l})$ were co-cultured on 96-well U-bottom plates for $4 \mathrm{~h}$ at $37^{\circ} \mathrm{C} 5 \% \mathrm{CO}_{2}$. The cells were then pelleted and incubated in $75 \mu \mathrm{l} /$ well fluorogenic caspase 3 substrate R2D2 (10 $\mu \mathrm{M}$, kindly provided by Dr. Beverly Packard, OncoImmunin Inc., Gaithersburg, MD) for 30 min followed by two washes with cold PBS. Sample acquisition and analysis are as described above. The cleaved caspase substrate has the following fluorescence peak characteristics: $\lambda_{\text {ex }}=505 \mathrm{~nm}$ and $\lambda_{\text {em }}=530 \mathrm{~nm}$, and can be detected in the FL1 channel. CTO can be detected in the FL2 channel. The percentage of specific killing = [\% caspase $^{+} \mathrm{CTO}^{+}$cells $/\left(\%\right.$ caspase ${ }^{+} \mathrm{CTO}^{+}$cells $+\%$ caspase $^{-}$ $\mathrm{CTO}^{+}$cells)] $\times 100 \%$.
In vivo $D C$ depletion and intracellular IFN- $\gamma$ staining

Age and gender-matched CD11c-DTR mice and WT littermates were injected i.p. with $12 \mathrm{ng} / \mathrm{g}$ body weight of diphtheria toxin (DT) (List Biological Laboratories, Campbell, CA) on day 0 and day $2[25,26]$. Six hours after the first DT injection, mice were infected i.p. with MVA at $5 \times 10^{6}$ PFU. Spleens were harvested on day 6 following the infection. Efficiency of DC depletion was determined by flow cytometry. Single cell suspensions (effector cells) were incubated with MVA-infected naïve splenocytes (target cells) in 96-well U-bottom plate (106/well effector and target cells each) in the presence of GolgiStop (BD Bioscience) for $12 \mathrm{~h}$. Cells were then blocked with antiCD16/CD32 FcyR III/II (2.4G2) and subjected to surface staining with anti-CD3 and CD8, as described above. Subsequent intracellular staining was performed using antimouse IFN- $\gamma$ (XMG1.2), rat-IgG1 isotype control (R3-34), and CytoFix/CytoPerm kit (BD Biosciences) according to manufacturer's instructions.

\section{Statistical analysis}

All statistical analyses were made with Microsoft Excel software (Microsoft). Statistical comparisons between data sets were made with a two-tailed homoscedastic Student's t-test.

\section{List of abbreviations}

VV: vaccinia virus; MVA: Modified vaccinia Ankara; DC: dendritic cell; MoDC: monocyte-derived DC; DTR: diphtheria toxin receptor; LCMV: lymphocytic choriomeningitis virus; NP: nuclear protein; BMDC: bone marrow derived DC; CM: complete medium; MOI: multiplicity of infection; PFU: plaque forming unit; i.p., intraperitoneal; WT: wild type; CTL: cytotoxic T lymphocyte; CTO: cell tracker orange; DT: diphtheria toxin.

\section{Authors' contributions}

LL designed, performed and analyzed all the experiments, wrote the manuscript. RC created the rMVA-GFP and rMVA-NP, and generated data in Fig. 2B. MBF participated in the design of the experiment and interpretation of data, revised the manuscript critically for important intellectual content. All authors read and approved the final manuscript. 


\section{Additional material}

\section{Additional file 1}

IFN- $\alpha$ was not detected in the supernatant of VV-infected DCs. (A) Immature BMDCs or purified CD11 $c^{+}$splenic DCs were either mock treated or infected with rVV-EGFP (a kind gift of Dr. Lawrence Corey, University of Washington, Seattle, WA) at a MOI of 10. Supernatant samples were collected at 10 and $24 \mathrm{~h}$ post infection, and IFN- $\alpha$ levels were measured by ELISA. These data are representative of three independent experiments. (B) VV-infected BMDCs produced a soluble factor(s) that abrogated the detection of IFN- $\alpha$ in the supernatant. Immature BMDCs were infected with $r M V A-G F P$ or $r V V-E G F P$ at a MOI of 10. Supernatant samples were collected at $24 \mathrm{~h}$ post infection. Various amounts of rmIFN- $\alpha$ were added into supernatant samples and ELISA was subsequently performed to detect IFN- $\alpha$.

Click here for file

[http://www.biomedcentral.com/content/supplementary/14712172-9-15-S1.pdf]

\section{Acknowledgements}

We thank Dr. Thomas S. Kupper, Chair of Dermatology Department at Brigham and Women's Hosptial, for reviewing the manuscript and providing general support; Dr. Qiong Zhong for the assistance in CDI Ic-DTR mice genotyping, Jay Omobono for help in formatting the illustrations. This study was supported by Dermatology Foundation Research Career Development Award, New England Research Center of Excellence/Biodefense and Emerging Infectious Diseases Career Development Fellowship to LL, NIH grant POIAI46007-05 to MBF, and NIH/NIAID grant UI9 AI05733003 to TSK.

\section{References}

I. Willis NJ: Edward Jenner and the eradication of smallpox. Scott Med J 1997, 42(4): I I8-I2I.

2. Neff JM, Levine RH, Lane JM, Ager EA, Moore H, Rosenstein BJ, Millar JD, Henderson DA: Complications of smallpox vaccination United States 1963. II. Results obtained by four statewide surveys. Pediatrics 1967, 39(6):916-923.

3. Neff JM, Lane JM, Pert JH, Moore R, Millar JD, Henderson DA: Complications of smallpox vaccination. I. National survey in the United States, 1963. New England Journal of Medicine 1967, 276(3): $125-132$

4. Mayr A, Stickl H, Muller HK, Danner K, Singer H: [The smallpox vaccination strain MVA: marker, genetic structure, experience gained with the parenteral vaccination and behavior in organisms with a debilitated defence mechanism (author's transI)]. Zentralbl Bakteriol [B] 1978, I 67(5-6):375-390.

5. Meyer H, Sutter G, Mayr A: Mapping of deletions in the genome of the highly attenuated vaccinia virus MVA and their influence on virulence. / Gen Virol I991, 72(Pt 5): I03।-1038.

6. Sutter G, Moss B: Nonreplicating vaccinia vector efficiently expresses recombinant genes. Proceedings of the National Academy of Sciences of the United States of America 1992, 89(22): |0847-|085I.

7. Ramirez JC, Gherardi MM, Esteban M: Biology of attenuated modified vaccinia virus Ankara recombinant vector in mice: virus fate and activation of $B$ - and $T$-cell immune responses in comparison with the Western Reserve strain and advantages as a vaccine. Journal of virology 2000, 74(2):923-933.

8. Wyatt LS, Earl PL, Eller LA, Moss B: Highly attenuated smallpox vaccine protects mice with and without immune deficiencies against pathogenic vaccinia virus challenge. Proceedings of the National Academy of Sciences of the United States of America 2004, I 0 I(I 3):4590-4595.
9. Earl PL, Americo JL, Wyatt LS, Eller LA, Whitbeck JC, Cohen GH, Eisenberg RJ, Hartmann CJ, Jackson DL, Kulesh DA, Martinez MJ, Miller DM, Mucker EM, Shamblin JD, Zwiers SH, Huggins JW, Jahrling PB, Moss B: Immunogenicity of a highly attenuated MVA smallpox vaccine and protection against monkeypox. Nature 2004, 428(6979): 182-185.

10. Belyakov IM, Earl P, Dzutsev A, Kuznetsov VA, Lemon M, Wyatt LS, Snyder JT, Ahlers JD, Franchini G, Moss B, Berzofsky JA: Shared modes of protection against poxvirus infection by attenuated and conventional smallpox vaccine viruses. Proceedings of the National Academy of Sciences of the United States of America 2003, I 00( I 6): $9458-9463$.

II. Drexler I, Staib C, Sutter G: Modified vaccinia virus Ankara as antigen delivery system: how can we best use its potential? Curr Opin Biotechnol 2004, I 5(6):506-5 I2.

12. Kastenmuller W, Drexler I, Ludwig H, Erfle V, Peschel C, Bernhard $H$, Sutter $G$ : Infection of human dendritic cells with recombinant vaccinia virus MVA reveals general persistence of viral early transcription but distinct maturation-dependent cytopathogenicity. Virology 2006, 350(2):276-288.

13. Henderson DA: The looming threat of bioterrorism. Science 1999, 283(5406): | 279-I282.

14. Parrino J, McCurdy LH, Larkin BD, Gordon IJ, Rucker SE, Enama ME, Koup RA, Roederer M, Bailer RT, Moodie Z, Gu L, Yan L, Graham BS: Safety, immunogenicity and efficacy of modified vaccinia Ankara (MVA) against Dryvax challenge in vaccinia-naive and vaccinia-immune individuals. Vaccine 2007, 25(8): $1513-1525$.

15. Carroll MW, Overwijk WW, Chamberlain RS, Rosenberg SA, Moss $B$, Restifo NP: Highly attenuated modified vaccinia virus Ankara (MVA) as an effective recombinant vector: a murine tumor model. Vaccine 1997, I 5(4):387-394.

16. Carroll MW, Moss B: Poxviruses as expression vectors. Curr Opin Biotechnol 1997, 8(5):573-577.

17. Guermonprez P, Valladeau J, Zitvogel L, Thery C, Amigorena S: Antigen presentation and $\mathbf{T}$ cell stimulation by dendritic cells. Annu Rev Immunol 2002, 20:62 I-667.

18. Drillien R, Spehner D, Hanau D: Modified vaccinia virus Ankara induces moderate activation of human dendritic cells. J Gen Virol 2004, 85(Pt 8):2 167-2175.

19. Liu L, Xu Z, Fuhlbrigge RC, Pena-Cruz V, Lieberman J, Kupper TS: Vaccinia virus induces strong immunoregulatory cytokine production in healthy human epidermal keratinocytes: a novel strategy for immune evasion. Journal of virology 2005 , 79(12):7363-7370.

20. Engelmayer J, Larsson M, Subklewe M, Chahroudi A, Cox WI, Steinman RM, Bhardwaj N: Vaccinia virus inhibits the maturation of human dendritic cells: a novel mechanism of immune evasion. J Immunol 1999, I63(I 2):6762-6768.

21. Humrich JY, Thumann P, Greiner S, Humrich JH, Averbeck M, Schwank C, Kampgen E, Schuler G, Jenne L: Vaccinia virus impairs directional migration and chemokine receptor switch of human dendritic cells. Eur J Immunol 2007, 37(4):954-965

22. Walzer T, Galibert L, De Smedt T: Poxvirus semaphorin A39R inhibits phagocytosis by dendritic cells and neutrophils. Eur J Immunol 2005, 35(2):39|-398.

23. Blanchard TJ, Alcami A, Andrea $P$, Smith GL: Modified vaccinia virus Ankara undergoes limited replication in human cells and lacks several immunomodulatory proteins: implications for use as a human vaccine. J Gen Virol 1998, 79(Pt 5): I I 59- I I 67.

24. Chahroudi A, Garber DA, Reeves P, Liu L, Kalman D, Feinberg MB: Differences and similarities in viral life cycle progression and host cell physiology after infection of human dendritic cells with modified vaccinia virus Ankara and vaccinia virus. Journal of virology 2006, 80(I 7):8469-848I.

25. Jung S, Unutmaz D, Wong P, Sano G, De los Santos K, Sparwasser T, Wu S, Vuthoori S, Ko K, Zavala F, Pamer EG, Littman DR, Lang RA: In vivo depletion of $C D I$ I $c(+)$ dendritic cells abrogates priming of CD8(+) T cells by exogenous cell-associated antigens. Immunity 2002, I 7(2):2 I |-220.

26. Tian T, Woodworth J, Skold M, Behar SM: In vivo depletion of CDI I c+ cells delays the CD4+ T cell response to Mycobacterium tuberculosis and exacerbates the outcome of infection. J Immunol 2005, I 75(5):3268-3272.

27. Belyakov IM, Wyatt LS, Ahlers JD, Earl P, Pendleton CD, Kelsall BL, Strober W, Moss B, Berzofsky JA: Induction of a mucosal cyto- 
toxic T-lymphocyte response by intrarectal immunization with a replication-deficient recombinant vaccinia virus expressing human immunodeficiency virus 89.6 envelope protein. Journal of virology 1998, 72(1 0):8264-8272.

28. Chahroudi A, Chavan R, Kozyr N, Waller EK, Silvestri G, Feinberg MB: Vaccinia virus tropism for primary hematolymphoid cells is determined by restricted expression of a unique virus receptor. Journal of virology 2005, 79(16): 10397-10407.

29. Amanna IJ, Slifka MK, Crotty S: Immunity and immunological memory following smallpox vaccination. Immunol Rev 2006, 21 1:320-337.

30. Crotty S, Felgner P, Davies H, Glidewell J, Villarreal L, Ahmed R: Cutting edge: long-term $B$ cell memory in humans after smallpox vaccination. J Immunol 2003, I 7 I ( I0):4969-4973.

31. Precopio ML, Betts MR, Parrino J, Price DA, Gostick E, Ambrozak DR, Asher TE, Douek DC, Harari A, Pantaleo G, Bailer R, Graham BS, Roederer M, Koup RA: Immunization with vaccinia virus induces polyfunctional and phenotypically distinctive CD8+ T cell responses. J Exp Med 2007, 204(6): I 405-1416.

32. Behboudi S, Moore A, Gilbert SC, Nicoll CL, Hill AV: Dendritic cells infected by recombinant modified vaccinia virus Ankara retain immunogenicity in vivo despite in vitro dysfunction. Vaccine 2004, 22(3I-32):4326-433I.

33. Behboudi S, Moore A, Hill AV: Splenic dendritic cell subsets prime and boost CD8 $T$ cells and are involved in the generation of effector CD8 T cells. Cell Immunol 2004, 228(I): I5-19.

34. Bender A, Albert M, Reddy A, Feldman M, Sauter B, Kaplan G, Hellman $W$, Bhardwaj $N$ : The distinctive features of influenza virus infection of dendritic cells. Immunobiology 1998, I 98(5):552-567.

35. Ho LJ, Wang JJ, Shaio MF, Kao CL, Chang DM, Han SW, Lai JH: Infection of human dendritic cells by dengue virus causes cell maturation and cytokine production. I Immunol 200I, 166(3): 1499-1506.

36. Geijtenbeek TB, Kwon DS, Torensma R, van Vliet SJ, van Duijnhoven GC, Middel J, Cornelissen IL, Nottet HS, KewalRamani VN, Littman DR, Figdor CG, van Kooyk Y: DC-SIGN, a dendritic cell-specific HIV-I-binding protein that enhances trans-infection of $T$ cells. Cell 2000, 100(5):587-597.

37. Moutaftsi M, Mehl AM, Borysiewicz LK, Tabi Z: Human cytomegalovirus inhibits maturation and impairs function of monocyte-derived dendritic cells. Blood 2002, 99(8):2913-2921.

38. Servet-Delprat C, Vidalain PO, Azocar O, Le Deist F, Fischer A, Rabourdin-Combe $\mathrm{C}$ : Consequences of Fas-mediated human dendritic cell apoptosis induced by measles virus. Journal of virology 2000, 74(9):4387-4393.

39. Servet-Delprat C, Vidalain PO, Bausinger H, Manie S, Le Deist F, Azocar O, Hanau D, Fischer A, Rabourdin-Combe C: Measles virus induces abnormal differentiation of CD40 ligand-activated human dendritic cells. J Immunol 2000, 164(4): 1753-1760.

40. Oie KL, Pickup DJ: Cowpox virus and other members of the orthopoxvirus genus interfere with the regulation of NFkappaB activation. Virology 200I, 288(I): I75-I87.

41. Yoshimura S, Bondeson I, Foxwell BM, Brennan FM, Feldmann M Effective antigen presentation by dendritic cells is NF-kappaB dependent: coordinate regulation of MHC, co-stimulatory molecules and cytokines. Int Immunol 200I, I3(5):675-683.

42. Seet BT, Johnston JB, Brunetti CR, Barrett JW, Everett H, Cameron C, Sypula J, Nazarian SH, Lucas A, McFadden G: Poxviruses and immune evasion. Annual Review of Immunology 2003, 21:377-423.

43. Colamonici OR, Domanski P, Sweitzer SM, Larner A, Buller RM: Vaccinia virus BI8R gene encodes a type I interferon-binding protein that blocks interferon alpha transmembrane signaling. J Biol Chem 1995, 270(27): I5974-15978.

44. Symons JA, Alcami A, Smith GL: Vaccinia virus encodes a soluble type I interferon receptor of novel structure and broad species specificity. Cell I995, 8 I (4):55I-560.

45. Antoine G, Scheiflinger F, Dorner F, Falkner FG: The complete genomic sequence of the modified vaccinia Ankara strain: comparison with other orthopoxviruses. Virology 1998 244(2):365-396.

46. Lande R, Giacomini E, Grassi T, Remoli ME, lona E, Miettinen M, Julkunen I, Coccia EM: IFN-alpha beta released by Mycobacterium tuberculosis-infected human dendritic cells induces the expression of CXCL I0: selective recruitment of NK and activated T cells. Journal of Immunology 2003, I 70(3): I I74- I I82.
47. Montoya M, Schiavoni G, Mattei F, Gresser I, Belardelli F, Borrow P, Tough DF: Type I interferons produced by dendritic cells promote their phenotypic and functional activation. Blood 2002, 99(9):3263-327|

48. Dobbelstein $M$, Shenk T: Protection against apoptosis by the vaccinia virus SPI-2 (BI3R) gene product. Journal of virology 1996, 70(9):6479-6485.

49. Norbury CC, Malide D, Gibbs JS, Bennink JR, Yewdell JW: Visualizing priming of virus-specific CD8+ $T$ cells by infected dendritic cells in vivo. Nat Immunol 2002, 3(3):265-27I.

50. Norbury CC, Basta S, Donohue KB, Tscharke DC, Princiotta MF, Berglund P, Gibbs J, Bennink JR, Yewdell JW: CD8+ T cell crosspriming via transfer of proteasome substrates. Science 2004, 304(5675): |3|8-|32|.

5I. Kennedy R, Poland GA: T-Cell epitope discovery for variola and vaccinia viruses. Rev Med Virol 2007, I7(2):93-II3.

52. Chavan R, Marfatia KA, An IC, Garber DA, Feinberg MB: Expression of CCL20 and granulocyte-macrophage colony-stimulating factor, but not Flt3-L, from modified vaccinia virus ankara enhances antiviral cellular and humoral immune responses. Journal of virology 2006, 80(I 5):7676-7687.

53. Carroll MW, Moss B: Host range and cytopathogenicity of the highly attenuated MVA strain of vaccinia virus: propagation and generation of recombinant viruses in a nonhuman mammalian cell line. Virology 1997, 238(2): 198-2II.

54. Pulendran B, Lingappa J, Kennedy MK, Smith J, Teepe M, Rudensky A Maliszewski CR, Maraskovsky E: Developmental pathways of dendritic cells in vivo: distinct function, phenotype, and localization of dendritic cell subsets in FLT3 ligand-treated mice. J Immunol 1997, I59(5):2222-223 I.

55. Pulendran B, Smith JL, Caspary G, Brasel K, Pettit D, Maraskovsky E, Maliszewski CR: Distinct dendritic cell subsets differentially regulate the class of immune response in vivo. Proceedings of the National Academy of Sciences of the United States of America 1999, 96(3): $1036-104 \mid$

56. Liu L, Usherwood EJ, Blackman MA, Woodland DL: T-cell vaccination alters the course of murine herpesvirus 68 infection and the establishment of viral latency in mice. Journal of virology 1999, 73( I 2):9849-9857.

57. Sailaja G, Husain S, Nayak BP, Jabbar AM: Long-term maintenance of gp I 20-specific immune responses by genetic vaccination with the HIV-I envelope genes linked to the gene encoding FIt-3 ligand. J Immunol 2003, I 70(5):2496-2507.

58. Liu L, Chahroudi A, Silvestri G, Wernett ME, Kaiser WJ, Safrit JT, Komoriya A, Altman JD, Packard BZ, Feinberg MB: Visualization and quantification of $T$ cell-mediated cytotoxicity using cellpermeable fluorogenic caspase substrates. Nat Med 2002, 8(2): $185-189$

Publish with Bio Med Central and every scientist can read your work free of charge

"BioMed Central will be the most significant development for disseminating the results of biomedical research in our lifetime. "

Sir Paul Nurse, Cancer Research UK

Your research papers will be:

- available free of charge to the entire biomedical community

- peer reviewed and published immediately upon acceptance

- cited in PubMed and archived on PubMed Central

- yours - you keep the copyright
BioMedcentral 